\title{
Verification of Macro- and Micronutrient Intake in the First Year of Roux-En-Y Gastric Bypass Using MSM Method
}

\author{
Caroline Frehner ${ }^{*}$, Marilia R. Zaparolli², Magda R. R. da Cruz ${ }^{3}$, Antônio C. L. Campos², \\ Maria Eliana M. Schieferdecker ${ }^{2}$, Alcides J. B. Filho ${ }^{4}$ \\ ${ }^{1}$ Clinical Hospital of Federal University of Parana (UFPR), Curitiba, Brazil \\ ${ }^{2}$ Federal University of Parana (UFPR), Curitiba, Brazil \\ ${ }^{3}$ Pontifical Catholic University of Parana (PUCPR), Curitiba, Brazil \\ ${ }^{4}$ Cevip-Paraná Laparoscopy Center, Curitiba, Brazil \\ Email: *carol.frehner@hotmail.com, mariliazaparolli@gmail.com, magda.cruz@pucpr.br, aclcampos@hotmail.com, \\ meliana@ufpr.br, ajbranco@terra.com.br
}

How to cite this paper: Frehner, C., Zaparolli, M.R., da Cruz, M.R.R., Campos, A.C.L., Schieferdecker, M.E.M. and Filho, A.J.B. (2017) Verification of Macro- and Micronutrient Intake in the First Year of Roux-En-Y Gastric Bypass Using MSM Method. Food and Nutrition Sciences, 8, 392401.

https://doi.org/10.4236/fns.2017.84027

Received: December 22, 2016

Accepted: April 21, 2017

Published: April 24, 2017

Copyright ( $\odot 2017$ by authors and Scientific Research Publishing Inc. This work is licensed under the Creative Commons Attribution International License (CC BY 4.0).

http://creativecommons.org/licenses/by/4.0/

\section{(c) (i) Open Access}

\begin{abstract}
Background: Bariatric surgery is an alternative treatment for obesity. However, physicians need to be aware of the possible consequences of nutritional deficiencies with this type of surgery. This study aimed to determine the prevalence of inadequacy of macro- and micronutrients from the diet in patients undergoing Roux-en-Y gastric bypass after 3, 6, and 12 months postoperatively. Methods: We performed a longitudinal, observational, clinical study during preoperatively and 3-, 6-, and 12 -month postoperatively ( $\mathrm{n}=95 \mathrm{pa}-$ tients). We collected information from medical records of patients in a Reference Clinic of Bariatric Surgery. Quantitative food intake was analyzed by ADS Nutri ${ }^{\circledR}$ and Multiple Source Method ${ }^{\circledR}$ software. The obtained data were compared with the daily-recommended intake in accordance with specific guidelines for bariatric surgery. Data were analyzed using t-tests, MannWhitney test, one-way analysis of variance (ANOVA), and Tukey's test. Results: There was a high prevalence of inadequacy of macronutrients and micronutrients from food in the postoperatively period. However, only vitamin B12 intake was adequate based on the daily recommended intake. Conclusions: Our study suggests that the intake of nutrients by feeding is below current recommendations. Individual nutritional counseling with a therapeutic plan for adequate nutrition and prescription supplements are important to ensure that nutritional recommendations are adhered to.
\end{abstract}

\section{Keywords}

Macronutrients, Micronutrients, Bariatric Surgery, Gastric Bypass, Food Intake 


\section{Introduction}

Obesity is a metabolic and multifactorial disease associated with genetic, behavioral, environmental, and endocrine disorders. Therefore, obesity is considered the epidemic of the century, as well as a major problem of global public health [1]. Obesity is the second leading cause of preventable and premature death in the United States [2]. In Brazil, $50.8 \%$ of the population is overweight and $17.5 \%$ is obese [3].

Conventional treatments for obesity include nutritional counseling, physical activity, drug treatment, and psychological treatment [4]. Surgical intervention is an alternative treatment if conventional treatments fail. [5]. The Roux-en-Y gastric bypass corresponds to $49 \%$ of all bariatric surgeries performed worldwide [6].

Patients undergoing this surgical technique are at high risk of developing nutritional deficiencies, because of reduced absorption, after intestinal bypass [7]. The combination of restrictive and disabsorptive components increases the nutritional risk, requiring intensive and continuous nutritional monitoring [8]. Moreover, the prevalence of symptoms, such as nausea, vomiting, diarrhea, dumping syndrome, and food intolerance, is high in Roux-en-Y gastric bypass, contributing to development of micro- and macronutrient deficiency [9].

The main deficiency of macronutrients after Roux-en-Y gastric bypass occurs because of a lack of protein [10]. Deficiencies in micronutrients postoperatively involve iron, folate, B vitamins (mainly B12), calcium, vitamin D, selenium and zinc [11].

Anatomical and physiological changes can affect food intake in patients who undergo Roux-en-Y gastric bypass. Correcting deficiencies in micro- and macronutrients to maintain adequate nutritional status is important. However, there is a lack of studies on Roux-en-Y gastric bypass that quantitatively assess nutrients from food postoperatively. Therefore, this study aimed to determine the prevalence of inadequacy of macro- and micronutrients at 3, 6, and 12 months postoperatively in patients who underwent Roux-en-Y gastric bypass.

\section{Materials and Methods}

\subsection{Study Design}

We performed a longitudinal, observational, retrospective, clinical study during preoperatively and 3-, 6-, and 12-month postoperatively. We studied patients in a reference bariatric surgery clinic. Approval for the study was obtained by the Ethics Committee of the Pontifical Catholic University of Paraná (PUCPR) under the following registration number: 13491913.8.0000.0020.

\subsection{Sample}

The sample population was selected by convenience. Inclusion criteria were as follows: adult patients of both sexes underwent Roux-en-Y gastric bypass from 2003 to 2014; nutritional records included preoperative data and data at 12 months postoperatively; and there was at least one nutritional record at 3 or 6 
months postoperatively.

\subsection{Nutritional Record Information}

Data were collected from the electronic nutritional records. The following information was collected: name, sex, age, initial weight and weight at each period, height, and 24-h food recall recorded at 3-, 6-, and 12-month visits. We calculated body mass index (BMI) and the percentage of excess weight loss (\% EWL) [12]. The nutritionist and the surgical team collected nutritional data and medical data, respectively. The same surgeon performed all surgeries.

\subsection{Analysis of Food Intake}

The food intake data were assessed from quantitative analysis of 24 -h food recall recorded at three time points. Estimation of food intake can be performed from two repeated measures that include different days of the week and periods during 1 year [13]. For this analysis, we used ADS Nutri ${ }^{\circledR}$ diet software (http://www.adsnutri.com.br/). Energy, carbohydrates, proteins, lipids, fiber, vitamin B12, iron, calcium, zinc, and selenium were evaluated. The usual intake of micronutrients was calculated using the Multiple Source Method ${ }^{\circledR}$ software (https://msm.dife.de/), which controls individual variability using statistics.

\subsection{Analysis of the Prevalence of Inadequate Macronutrients and Micronutrients}

For determining the inadequacy of macronutrients and micronutrients, we used quantitative analysis of food intake and compared it with specific recommendations. Micronutrients were compared with the estimated average requirement according to sex and age, and macronutrients were compared with the guidelines for bariatric surgery [10].

\subsection{Statistical Analysis}

We used SPSS version 2.0 (SPSS Inc., Chicago, IL, USA) to perform normal tests, categorize variables as parametric and non-parametric, for descriptive analysis, and to compare means. Parametric variables analyzed by descriptive statistics are shown as the mean and standard deviation, while nonparametric variables are shown as median, minimum, and maximum values. The t-test was used for independent samples and the Mann-Whitney test was used to compare the means and medians of the three periods. ANOVA and Tukey's test were used for comparison of means between different periods. The level of significance was $\mathrm{p}<$ 0.05 .

\section{Results}

The sample consisted of 95 patients. At 3 and 6 months postoperatively, data from 92 and 88 patients were available, respectively, because of the absence of some patients from consultations. The final study population consisted of 84 (88.4\%) women. Age ranged 20 - 64 years. For preoperative weight, median 
weight was $104 \mathrm{~kg}$, with a minimum of $75 \mathrm{~kg}$ and maximum of $178 \mathrm{~kg}$ (Table 1).

There was an important reduction in weight and BMI at 3, 6, and 12 months compared with that before surgery. The mean BMI of patients preoperatively was $39.3 \mathrm{~kg} / \mathrm{m}^{2}$ and $31.22 \mathrm{~kg} / \mathrm{m}^{2}$ at 3 months after surgery, with a decline to $26.63 \mathrm{~kg} / \mathrm{m}^{2}$ at 12 months postoperatively. EWL at 3 months postoperatively was $56.39 \% \pm 17.32 \%$. At 6 months, EWL reached 74.5\% (33\% - 139\%), and at 12 months, it was $88.57 \% \pm 23.7 \%$ (Table 1 ).

Medium energy intake increased over the postoperative period, with a significant increase compared with energy recommendations at each time point ( $\mathrm{p}<$ $0.05)$. However, there was no significant difference in medium energy intake of the three periods after surgery compared with that before surgery $(p>0.05)$. The highest percentage of inadequacy was protein intake at 12 months postoperatively (66.32\%). The percentage of inadequate energy and lipids was higher at 6 months postoperatively, during which no patients had adequate intake of these variables, compared with 3 and 12 months postoperatively. The prevalence of inadequate zinc intake gradually declined over the three periods (Table 2). There was a gradual increase in the intake of micronutrients, with the exception

Table 1. Characteristics of the study population pre- and post-surgery.

\begin{tabular}{ccccc}
\hline Variables & $\begin{array}{c}\text { Pre-surgery } \\
\text { Average/Median* }\end{array}$ & $\begin{array}{c}3 \text { months } \\
\text { Average/Median* }\end{array}$ & $\begin{array}{c}\text { 6 months } \\
\text { Average/Median* }\end{array}$ & $\begin{array}{c}12 \text { months } \\
\text { Average/Median* }\end{array}$ \\
\hline Number of patients & 95 & 92 & 88 & 95 \\
Age (years) & $46(20-64)$ & - & - & - \\
Height $(\mathrm{m})$ & $1.63 \pm 0.07$ & - & - & $71(47-127.5)$ \\
Weight $(\mathrm{kg})$ & $104(75-178)$ & $83(65-140)$ & $75.45(56-131)$ & $26,63(19.07-48.58)$ \\
BMI $\left(\mathrm{kg} / \mathrm{m}^{2}\right)$ & $39.3(29-67.83)$ & $31.22(23.92-53.35)$ & $28.79(22.39-49.92)$ & $88.57 \pm 23.7$ \\
\% weight loss & - & $56.39 \pm 17.32$ & $74.5(33-139)$ & 8 \\
\hline
\end{tabular}

${ }^{\star}$ Mean $\pm \mathrm{SD} /$ median (minimum-maximum); Note: BMI, body mass index.

Table 2. Energy and macronutrient consumption at 3, 6, and 12 months postoperatively.

\begin{tabular}{|c|c|c|c|c|c|c|c|c|c|}
\hline & \multicolumn{3}{|c|}{3 Months } & \multicolumn{3}{|c|}{6 Months } & \multicolumn{3}{|l|}{12 Months } \\
\hline & 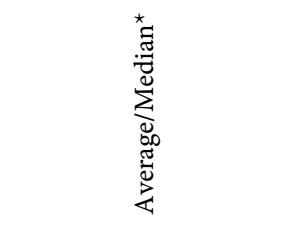 & 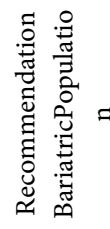 & 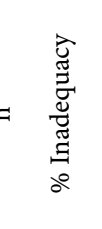 & 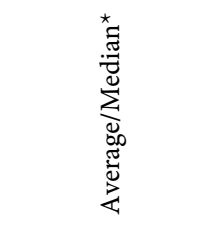 & 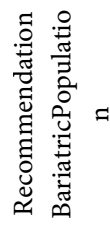 & 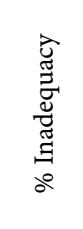 & 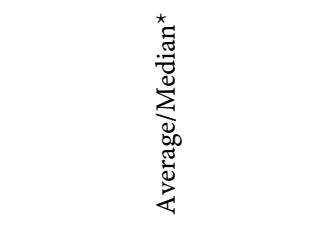 & 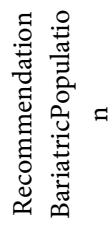 & 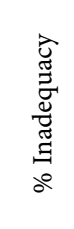 \\
\hline Energy (kcal) & $651.3 \pm 151.3^{\mathrm{aA}}$ & $800^{\mathrm{b}}$ & 85.9 & $729.57 \pm 149.38^{\mathrm{aA}}$ & $1000^{\mathrm{b}}$ & 100 & $902.35(803.29-1882.85)^{\mathrm{aA}}$ & $1200^{\mathrm{b}}$ & 85.26 \\
\hline Carbohydrate (g) & $77.53(40.63-142.69)^{\mathrm{aA}}$ & $130^{\mathrm{b}}$ & 96.74 & $92.39 \pm 21.72^{\mathrm{a}}$ & $130^{\mathrm{bA}}$ & 95.51 & $116.6(62.22-259.66)^{\mathrm{aA}}$ & $130^{\mathrm{b}}$ & 71.58 \\
\hline Protein (g) & $43.43 \pm 12.28^{\mathrm{aA}}$ & $60^{\mathrm{b}}$ & 82.4 & $47.73 \pm 12.08^{\mathrm{aA}}$ & $60^{\mathrm{b}}$ & 88.77 & $55.77 \pm 12.42^{\mathrm{aA}}$ & $60^{\mathrm{b}}$ & 66.32 \\
\hline Lipids (g) & $16.45(2.71-37.06)^{\mathrm{aA}}$ & $40^{\mathrm{b}}$ & 100 & $19.54 \pm 5.72^{\mathrm{aA}}$ & $40^{\mathrm{b}}$ & 100 & $24.42(7.2-55.63)^{\mathrm{aA}}$ & $40^{\mathrm{b}}$ & 93.69 \\
\hline
\end{tabular}

${ }^{*}$ Mean \pm SD/median (minimum-maximum); ${ }^{\text {a,b }}$ : Significant difference by Tukey’s test $(\mathrm{p}<0.05)$. The same letter does not indicate a significant difference. ${ }^{\mathrm{A}, \mathrm{B}}$ : Significant difference by one-way ANOVA and Tukey's test $(\mathrm{p}<0.05)$. The same letter does not indicate a significant difference. 
of zinc for men. Despite this increase, all of these nutrients were below the daily recommended intake (Table 3 ).

Unlike the other nutrients, Vitamin B12 was adequate in accordance with the recommendations. The usual intake of zinc in women, iron in older women, calcium in elderly men and women, and calcium and selenium, reached values close to or above $100 \%$ inadequacy (Table 4 ).

\section{Discussion}

In our study, over a 12-month postoperative period, there was a significant increase in \%EWL, which indicated surgical success. However, there was a high prevalence of inadequate macro- and micronutrients from food intake. Among

Table 3. Comparison of consumption of micronutrients at 3, 6, and 12 months postoperatively.

\begin{tabular}{|c|c|c|c|c|c|c|}
\hline & \multicolumn{2}{|l|}{3 Months } & \multicolumn{2}{|l|}{6 Months } & \multicolumn{2}{|l|}{12 Months } \\
\hline Micronutrients & 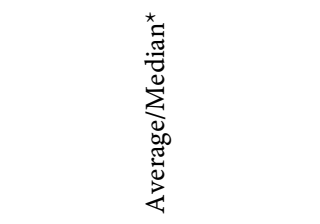 & 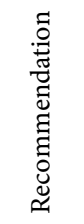 & 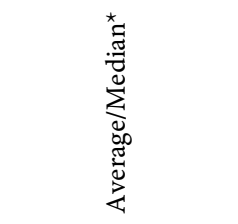 & 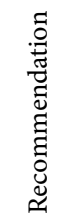 & 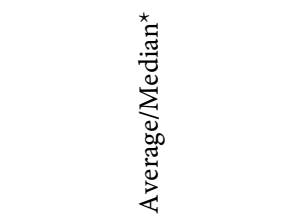 & 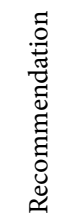 \\
\hline Calcium (mg) & $354.52(49.89-961.26)^{\mathrm{a}}$ & $800^{\mathrm{b}}$ & $350 \pm 165.39^{\mathrm{a}}$ & $800^{\mathrm{b}}$ & $398.41(91.88-1256.93)^{\mathrm{a}}$ & $800^{\mathrm{b}}$ \\
\hline Calcium elderly (mg) & $465.03(324.22-1048.56)^{\mathrm{a}}$ & $1000^{\mathrm{b}}$ & $495.33 \pm 190.78^{\mathrm{a}}$ & $1000^{\mathrm{b}}$ & $652.9(264.85-972.57)^{\mathrm{a}}$ & $1000^{\mathrm{b}}$ \\
\hline Zinc men(mg) & $7.39 \pm 3.36^{\mathrm{a}}$ & $9.4^{\mathrm{a}}$ & $10.86 \pm 2.44^{\mathrm{a}}$ & 9.4 & $9.04 \pm 3.74^{\mathrm{a}}$ & $9.4^{\mathrm{a}}$ \\
\hline Zinc women (mg) & $8.14 \pm 2.97^{\mathrm{a}}$ & $6,8^{\mathrm{b}}$ & $9.23 \pm 3.29^{\mathrm{a}}$ & $6.8^{\mathrm{b}}$ & $10.07 \pm 3.18^{\mathrm{a}}$ & $6,8^{\mathrm{b}}$ \\
\hline Iron adult women (mg & $3.98 \pm 1.32^{\mathrm{a}}$ & $8.1^{\mathrm{b}}$ & $4.46 \pm 1.33^{\mathrm{a}}$ & $8.1^{b}$ & $5.65 \pm 1.28^{\mathrm{a}}$ & $8.1^{\mathrm{b}}$ \\
\hline Iron elderly women (mg) & $4.69 \pm 1.11^{\mathrm{a}}$ & $5^{\mathrm{a}}$ & $5.55 \pm 1.79^{\mathrm{a}}$ & $5^{\mathrm{a}}$ & $4.54 \pm 0.93^{\mathrm{a}}$ & $5^{\mathrm{a}}$ \\
\hline Selenium (mcg) & $8.06(0.00-32.24)^{\mathrm{a}}$ & $45^{\mathrm{b}}$ & $3.57(0.00-38.66)^{\mathrm{a}}$ & $45^{\mathrm{b}}$ & $6.69(0.00-45.08)^{\mathrm{a}}$ & $45^{\mathrm{b}}$ \\
\hline B12 Vitamin (mcg) & $1.41(0.00-3.96)^{\mathrm{a}}$ & $2^{\mathrm{b}}$ & $2.54(1.13-3.96)^{\mathrm{a}}$ & $2^{\mathrm{b}}$ & $3.39(1.69-5.80)^{\mathrm{a}}$ & $2^{\mathrm{b}}$ \\
\hline
\end{tabular}

${ }^{\star}$ Mean \pm SD/median (minimum-maximum); ${ }^{\text {a,b }}$ : Significant difference by Tukey's test $(\mathrm{p}<0.05)$. The same letter does not indicate a significant difference.

Table 4. Recommendation and prevalence of inadequacy of micronutrients at 1 year postoperatively.

\begin{tabular}{|c|c|c|c|}
\hline Nutrients & Usual consumption & Recommendation & \% Inadequacy \\
\hline Calcium (mg) & $346.65 \pm 144.44$ & 800 & 99.95 \\
\hline Calcium elderly (mg) & $469.65 \pm 166.14$ & 1000 & 99.92 \\
\hline Zinc men (mg) & $10.17 \pm 0.72$ & 9.4 & 60.26 \\
\hline Zinc women (mg) & $9.14 \pm 0.98$ & 6.8 & 100 \\
\hline Iron men (mg) & $5.47 \pm 0.52$ & 6 & 83.39 \\
\hline Iron adult women (mg) & $4.76 \pm 0.37$ & 8.1 & 100 \\
\hline Iron elderly women (mg) & $4.84 \pm 0.28$ & 5 & 67 \\
\hline Selenium (mcg) & $8.30 \pm 3.85$ & 45 & 100 \\
\hline B12 Vitamin (mcg) & $2.48 \pm 0.004$ & 2 & 0 \\
\hline
\end{tabular}

Note: The data have been adjusted to variability using MSM statistical software. 
the micronutrients, vitamins had the lowest index of inadequacy.

The number of women in our study who had surgery was higher than that in men. This finding is consistent with a study that investigated the effect of bariatric surgery on weight loss, and showed that $72.6 \%$ of patients who underwent bariatric surgery were women [14].

A deficit in energy intake was found in our population. A previous study ( $\mathrm{n}=$ 36 patients) showed an intake of $322 \mathrm{kcal}$ preoperatively and $1060 \mathrm{kcal}$ at 6 months after bariatric surgery, using recall $24 \mathrm{~h}$ and Nutwin ${ }^{\circledR}$ software for nutrient calculation [22]. Similarly, another study on bariatric surgery in 93 patients showed a higher energy intake than that found in our study (849 \pm 329 $\mathrm{kcal}$ at 3 months and $1101 \pm 400 \mathrm{kcal}$ at 12 months postoperatively) [23]. However, despite the fact that the 24 -h dietary recall method is valid for postoperative follow-up and has a minimal risk of underestimating reduction in weight, these previous reports may have underestimated energy intake.

In our study, patients had inadequate protein intake. This finding is similar to results from another study ( $\mathrm{n}=137$ patients) that investigated progression of weight loss and anemia in patients undergoing Roux-en-Y gastric bypass [16]. This previous study showed $14.2 \pm 45.6 \mathrm{~g}$ of protein intake at 3 months and 58.5 $\pm 17.1 \mathrm{~g}$ at 12 months. Another study showed that 6 months after the bariatric surgery, protein intake was $47.11 \pm 17.70 \mathrm{~g}$ [15]. This inadequacy can lead to a reduction in body mass, decrease in metabolic rate, and physiological damage. A protein diet with the recommended amount increases satiety, increases weight loss, and improves body composition [17]. Therefore, maintenance of protein supplementation might achieve the recommended requirements. This supplementation requirement can also be explained by the fact that there is a deliberate reduction in calorie intake of $78 \%$ on average because of restrictions for surgery, which contributes to reducing protein intake. There is an association between intolerance to protein and a decrease in secretion of proteolytic enzymes. To avoid the risk of malnutrition, protein supplementation up to 6 months after surgery is recommended and may continue until supply is obtained through food [18].

The recommended $15 \mathrm{~g} /$ day fiber intake was not reached until 12 months after surgery in our study. Bariatric surgery leads to a decrease in the volume of eaten food, especially during the first months after surgery. However, changes in the nutritional quality of food intake that occur in the preoperative period must not occur during the postoperative period, as this will lead to health problems. We also analyzed fiber intake in post-surgical patients and found that fiber intake up to 12 months after surgery was less than the recommended intake [19]. This finding reflects the need for continuous nutritional education on an outpatient basis, encouraging the consumption of fruits, vegetables, whole grains, and high-fiber foods.

After Roux-en-Y gastric bypass, clinical symptoms are often due to a poor nutritional standard. This situation is due to changes in dietary pattern induced by the surgical procedure. Postoperative anatomical changes affect bile and pancreatic function, the speed of intestinal transit, production of hydrochloric acid, 
and the intestinal absorptive area [20]. There is a high risk of developing nutritional deficiencies after bariatric surgery because of the difficulty of maintaining proper nutrition [21]. In addition to all of the risk factors, there was an inadequate intake of micronutrients of patients in our study because of the difficulty of maintaining adequate food.

In the current study, there was a high percentage of inadequate iron intake. This finding is consistent with previous studies, which showed that $36 \%$ of patients have iron deficiency after 12 months of surgery. Another study showed that $86.11 \%$ of the population studied was below $85 \%$ of the recommended intake of iron [15]. This deficiency occurs not only due to low iron intake, but also in gastric hypochlorhydria and intolerance to red meat [20]. Guidelines recommend using elemental iron supplementation after surgery, and the daily recommendation is $45-60 \mathrm{mg}$ [21]. There may be a need for additional vitamin C concurrently to increase the absorption of iron [22].

Our study showed that the intake of vitamin B12 had the lowest prevalence of inadequate intake. This result may be due to nutritional counseling that is focused on encouraging consumption of food sources (eggs, milk, and dairy products) of this vitamin. However, a previous study showed a high prevalence of vitamin B12 deficiency in patients undergoing gastroplasty with intestinal bypass in Roux-en-Y gastric bypass (42.1\%) [21]. Despite many reports of vitamin B12 deficiency, it can vary from $12 \%-75 \%$ of the population after bariatric surgery. This variation is caused by the individual time taken to exhaust the stock of vitamin B12 in the liver ( 2 - 5 years). This is exacerbated because of reduced gastric production of hydrochloric acid and decreased production of intrinsic factors in the stomach [20]. Recommended supplementation of vitamin B12 may be orally at $1000 \mathrm{mcg} /$ day, intravascularly at $1000 \mathrm{mcg} / \mathrm{month}$, or $3000 \mathrm{mcg}$ every 6 - 12 months [21]. The adequacy of vitamin B12 intake in our study population may have been achieved as a result of preoperative and postoperative encouragement to consume food sources rich in this nutrient, the fact that no patients were vegetarians, or underestimation of the food composition table values.

There was a high inadequate zinc intake in patients in this study. This inadequacy of zinc may be related to food intolerance [22]. More than 18 months after surgery, $20 \%$ - $24 \%$ of the population is estimated to develop zinc deficiency [23]. Absorption of zinc requires an acidic environment in the stomach, and this absorption occurs in the proximal portion of the intestine [23]. This absorption is compromised by anatomical changes because of bariatric surgery. The recommendation for zinc supplementation is $50-60 \mathrm{mg}$ of elemental zinc per day [11].

The high percentage of inadequate calcium intake observed in our population is a concern. Low intake of calcium was also investigated in a study that evaluated patients $(n=36)$ undergoing gastroplasty with intestinal bypass in Rouxen-Y gastric bypass during the preoperatively and 6 months postoperatively and showed an average calcium intake of $597.03 \pm 289.55 \mathrm{mg}$ among participants [15]. A reduction in calcium intake and poor tolerance to milk products can lead to calcium deficiency, which leads to a high long-term risk of developing bone 
disease [20]. Dairy products are also good sources of vitamin D. Therefore, reducing dairy product intake has consequences for ingestion and absorption of calcium and vitamin $\mathrm{D}$. This increases the risk of developing osteopenia, osteoporosis, and osteomalacia [24].

This study showed no adequancy of selenium with food intake. The main dietary sources of selenium include nuts, salmon, wheat bran, and raw oysters. By analyzing data from food consumption of our population, we found a low intake of these foods as micronutrient sources. Educating patients and informing them of the main food sources are important for continuous, adequate nutrition.

Patients who undergo bariatric surgery may already show changes in plasma levels of micronutrients in the preoperative period because obesity with a poor quality of diet is a cause of nutrient deficiency. As mentioned above, bariatric surgery causes anatomical and physiological changes that affect the quantity and quality of food intake and absorption. Therefore, nutritional deficiency is directly related to preoperative status and the surgical method, and is also exacerbated by inadequate food intake post-surgically. Therefore, prevention and correction of deficiencies in vitamins and minerals should be initiated preoperatively, minimizing the risk of postoperative deficiency.

\section{Conclusion}

Food intake deficits of macro- and micronutrients result from eating habits in the first year of Roux-en-Y gastric bypass, indicating an insufficient intake of food sources. Because of the high risk of developing serious nutritional deficiencies, continuous nutritional monitoring, and encouraging adherence to a nutritional plan in accordance with the recommendations proposed for post-bariatric surgery are necessary. Furthermore, a therapeutic plan with supplements should be established, noting the individual nutritional needs.

\section{Acknowledgements}

Clínica de Videolaparoscopia do Paraná-Cevip.

\section{Ethical Approval}

All procedures performed in studies involving human participants were in accordance with the ethical standards of the institutional and/or national research committee and with the 1964 Helsinki declaration and its later amendments or comparable ethical standards. For this type of study, formal consent is not required.

\section{Conflict of Interest}

The authors declare that they have no conflicts of interest.

\section{References}

[1] Sociedade Brasileira de Diabetes. Therapeutic Conduct in Type 2 Diabetes-SBD, 2014. Posicionamento Oficial SBD n ${ }^{\circ} 01 / 2014$. 
http://www.diabetes.org.br/ebook/component/k2/item/83-conduta-terapeutica-nodiabetes-tipo-2-algoritmo-sbd-2014

[2] Centers for Disease Control And Prevention-CDC. Overweight and Obesity. Adult Obesity Facts, 2014. http://www.cdc.gov/obesity/data/adult.html

[3] Vigilância de fatores de risco e proteção para doenças crônicas por inquérito telefônico-VIGITEL. Excess Weight and Obesity, 2013. http://www.abeso.org.br/uploads/downloads/73/553a2458a9fae.pdf

[4] Bult, M.J., Van Dalen, T. and Muller, A.F. (2008) Surgical Treatment of Obesity. European Journal of Endocrinology, 158, 135-145.

https://doi.org/10.1530/EJE-07-0145

[5] Zeze, J.L.M., Tomaz, C.A.B., Nassif, P.A.N., Lima, J.H., Sansano, L.R.Z. and Zeve, C.H. (2013) Obese Patients with dIabetes Mellitus Type 2 Undergoing Gastric Bypass in Roux-en-Y: Analysis of Results and Its Influence in Complications. $A B C D$. Arquivos Brasileiros de Cirurgia Digestiva (São Paulo), 26, 47-52. https://doi.org/10.1590/S0102-67202013000600011

[6] Buchwald, H. and Oien, D.M. (2008) Metabolic/Bariatric Surgery Worldwide. $O b$ esity Surgery, 19, 1605-1611. https://doi.org/10.1007/s11695-009-0014-5

[7] Kim, M.K., Kim, W., Kown, H.S., Baek, K.H. and Kim, E.K. (2014) Effects of Bariatric Surgery on Metabolic and Nutritional Parameters in Severely Obese Korean $\mathrm{Pa}$ tients with Type 2 Diabetes: A Prospective 2-Year Follow Up. Journal of Diabetes Investigation, 5, 221-227. https://doi.org/10.1111/jdi.12137

[8] Isom, K.A., Andromalos, L., Ariagno, M., Hartman, K., Mogensen, K.M., Stephanides, K. and Shikora, S. (2014) Nutrition and Metabolic Support Recommendations for the Bariatric Patient. Nutrition in Clinical Practice. Nutrition in Clinical Practice, 29, 718-739. https://doi.org/10.1177/0884533614552850

[9] Elrazek, A.E.M.A.A., Elbanna, A.E.M. and Bilasy, S.E. (2014) Medical Management of Patients after Bariatric Surgery: Principles and Guidelines. World Journal of Gastrointestinal Surgery, 6, 220-228.

[10] Mechanick, J.I., Kushner, R.F., Sugerman, H.J., Gonzalez-Campoy, J.M., et al. (2009) American Association of Clinical Endocrinologists, the Obesity Society, and American Society for Metabolic \& Bariatric Surgery Medical Guidelines for Clinical Practice for the Perioperative Nutritional, Metabolic, and Nonsurgical Support of the Bariatric Surgery Patient. Obesity, 17, S3-S72.

https://doi.org/10.1038/oby.2009.28

[11] Ramos, N.M., Magno, F.C., Cohen, L., Rosado, E.L. and Carneiro, J.R. (2015) Weight Loss and Nutritional Anemia in Patients Submitted to Roux-en-Y Gastric Bypass on Use of Vitamin and Mineral Supplementation. ABCD. Arquivos Brasileiros de Cirurgia Digestiva (São Paulo), 28, 44-47. https://doi.org/10.1590/S0102-67202015000100012

[12] World Health Organization (WHO) Obesity: Preventing and Managing the Global Epidemic. Report of a WHO Consultation. http://www.who.int/nutrition/publications/obesity/WHO_TRS_894/en/

[13] Hoffmann, K. (2002) Estimating the Distribution of Usual Dietary Intake by ShortTerm Measurements. European Journal of Clinical Nutrition, 56, 53-62.

[14] Buchwald, H., Avidor, Y., Braunwlad, E., Jensen, M.D., Pories, W., Fahrbach, K. and Schoelles, K. (2004) Bariatric Surgery: A Systematic Review and Meta-Analysis. $J A M A, 292,1724-1737$. https://doi.org/10.1001/jama.292.14.1724

[15] Moize, V.L., Geliebter, A., Gluck, M.E., Yahav, E., Lorence, M., Colarusso, T., Drake, V. and Flancbaum, L. (2003) Obese Patients Have Inadequate Protein Intake Related to Protein Intolerance up to 1 Year Following Roux-en-Y Gastric Bypass. 
Obesity Surgery, 13, 23-28. https://doi.org/10.1381/096089203321136548

[16] Gobato, R.C., Chaves, D.F.S. and Chaim, E.A. (2014) Micronutrient and Physiologic Parameters before and 6 Months after RYGB. Surgery for Obesity and Related Diseases, 10, 944-951. https://doi.org/10.1016/j.soard.2014.05.011

[17] Faria, S.L., Faria, O.P., Buffington, C., Cardeal, M.A. and Ito, M.K. (2011) Dietary Protein Intake and Bariatric Surgery Patients: A Review. Obesity Surgery, 21, 17981805. https://doi.org/10.1007/s11695-011-0441-y

[18] Coppini, L.Z. (2015) Nutrition and Metabolism in Metabolic and Bariatric Surgery: Nutritional Guidelines for Post-Operative Vertical Gastrectomy. Rubio, Rio de Janeiro.

[19] Bavaresco, M., Paganini, S., Lima, T.P., Salgado Jr., W., Ceneviva, R., Dos Santos J.E. and Nonino-Borges, C.B. (2010) Nutritional Course of Patients Submitted to Bariatric Surgery. Obesity Surgery, 20, 716-721. https://doi.org/10.1007/s11695-008-9721-6

[20] Bordalo, L.A., Mourão, D.N. and Bressan, J. (2010) Nutritional Deficiencies after Bariatric Surgery: Why They Happen? Acta Médica Portuguesa, 24, 1021-1028.

[21] Alexandrou, A., Tsoka, E., Armeni, E., Rizos, D., Diamantis, T., Augolea, A., Panoulis, C., Liakakos, T. and Lambrinoudaki, I. (2015) Determinants of Secondary Hyperparathyroidism in Bariatric Patients after Roux-en-Y Gastric Bypass or Sleeve Gastrectomy: A Pilot Study. International Journal of Endocrinology, 2015, Article ID: 984935. https://doi.org/10.1155/2015/984935

[22] Lima, K.V.G., Costa, M.J.C., Gonçalves, M.C.R. and Sousa, B.S. (2013) Micronutrient Deficiencies in the Pre-Bariatric Surgery. ABCD. Arquivos Brasileiros de Cirurgia Digestiva (São Paulo), 26, 63-66. https://doi.org/10.1590/S0102-67202013000600014

[23] Gletsu-Miller, N. and Wright, B.N. (2013) Mineral Malnutrition Following Bariatric Surgery. Advances in Nutrition: An International Review Journal, 4, 506-517. https://doi.org/10.3945/an.113.004341

[24] Sarmento, R., Casagrande, D. and Schaan, B. (2014) Bariatric Surgery in the Treatment of Obesity: Impact on Bone Metabolism. Revista Hospital Universitário Pedro Ernesto, Rio de Janeiro, 13, 87-93. https://doi.org/10.12957/rhupe.2014.9811

\section{Scientific Research Publishing}

Submit or recommend next manuscript to SCIRP and we will provide best service for you:

Accepting pre-submission inquiries through Email, Facebook, LinkedIn, Twitter, etc. A wide selection of journals (inclusive of 9 subjects, more than 200 journals)

Providing 24-hour high-quality service

User-friendly online submission system

Fair and swift peer-review system

Efficient typesetting and proofreading procedure

Display of the result of downloads and visits, as well as the number of cited articles

Maximum dissemination of your research work

Submit your manuscript at: http://papersubmission.scirp.org/

Or contact fns@scirp.org 